\title{
The effect of temperature and growth density on the development and yield of two- and multi-rowed barley varieties
}

\author{
Kirsti ÄyräväInen and Juhani PaAtela \\ Department of Plant Husbandry, University of Helsinki \\ 00710 Helsinki, Finland
}

Received January 16, 1974

\begin{abstract}
The effects of temperature and plant spacing on growth, on the distribution of biological mass within the plant, and on yield were studied with seven barley varieties at two temperatures, $10^{\circ} \mathrm{C}$ and $20^{\circ} \mathrm{C}$, and two growth densities, 3 and 13 plants per pot.

Vegetative development at $20^{\circ} \mathrm{C}$ was nearly twice as fast as at $10^{\circ} \mathrm{C}$. After the plants had entered the reproductive phase, the difference in developmental rate became smaller. Plants grown at the lower temperature produced much higher total biological yields and grain yields than plants grown at the higher temperature. Percentage proportion of leaves was higher and proportion of culms lower at $20^{\circ} \mathrm{C}$ than at $10^{\circ} \mathrm{C}$. Temperature had no significant effect on number of culms and 1000-grain weight. Number of grains per ear was higher at $10^{\circ} \mathrm{C}$ than at $20^{\circ} \mathrm{C}$.

Total biological yield per pot and grain yield per pot were larger when the plants were grown in dense populations. More culms and larger yields per individual plant were produced in sparse populations. Growth density did not affect the number of grains per ear. Length of ear and 1000-grain weight were larger in sparse than dense populations.

Two-rowed barley varieties gave significantly higher total biological yields and slightly higher grain yields than multi-rowed varieties. There were no differences between the two types of barley in proportions of leaves, culms and roots. As expected, number of culms and 1000-grain weight were higher, and number of grains per ear was lower, in the two-rowed than in the multi-rowed varieties.

Among the various yield components, number of culms explained most of the yield. The number of grains per ear explained a smaller proportion, and 1000-grain weight a larger proportion, of the yield of the two-rowed varieties than of that of the multirowed varieties. In both types of barley there was a significant positive correlation between number of culms and 1000-grain weight. The number of grains per ear was not correlated with the number of culms; neither was it correlated with 1000-grain weight. There were differences between the two-row and multi-row types in correlations between culm numbers, leaves and roots. The distribution of biological yield between various plant parts in different phases of development did not affect the grain yield.
\end{abstract}


The adoption of greenhouses and growth cabinets for research purposes has considerably improved the possibilities of studying the effects of various environmental factors on the growth pattern and yield of plants. The effects of photoperiod, radiation and temperature in particular have been subject to extensive investigation. In cereal plants, studies have been made on the influence of environmental factors on growth (FRIEND 1966, Aspinall et al. 1964, Aspinall 1966 and 1969, Friend et al. 1963) as well as on yield and the various yield components (Thorne 1966, CAmpbell et al. 1968, Guitard 1960, ThORNe et al. 1968, LANGer 1967, FARIS et al. 1969).

Early in 1971 a greenhouse experiment was conducted at the Department of Plant Husbandry of the University of Helsinki (University Farm Viik) to study the effect of temperature on the growth of some Finnish barley varieties, on the distribution of biological yield within the plant in various stages of development, and on the formation and composition of yield. The main purpose of this work was to examine possible differences between tworowed and multi-rowed barleys.

\section{Material and methods}

Varieties with differing growth rates were selected for the experiment. These included four two-row varieties: Arvo, Birgitta, Arla, and a mutant line $\mathrm{Hja} 34004$ from Hankkija Plant Breeding Station; and three multi-row varieties: Tammi, Pirkka, and Pomo. Among the two-row barleys, Arvo and $\mathrm{Hja} 34003$ have the longest growing periods while Arla is an early-maturing variety. The earliest varieties were Tammi and Pirkka. Pomo represents a late-maturing type of multi-rowed barley.

The two-rowed Arla and the multi-rowed Pomo have both two- and multirowed inheritance in their genotype. The other varieties have no elements of the opposite row type in their ancestry.

The plants were grown in five-litre pots with a cross-sectional area of 284 $\mathrm{cm}^{2}$, in a mixture of peat and sand. Two growth densities, 3 and 13 plants per pot, and three replications were used. Adequate water supply was provided by an automatic sub-irrigation system with a constant level of ground-water table. Additional feeding was given twice, at the seedling and early tillering stages, by administering a nutrient solution specifically prepared for peat soil. The plants were grown at two constant temperatures, $10^{\circ} \mathrm{C}$ and $20^{\circ} \mathrm{C}$. After the reproductive phase had been reached, rising outdoor temperatures caused the lower temperature regime to pass the $10^{\circ}$ mark, and as the plants approached full maturity it became impossible to prevent the temperature in both greenhouses from exceeding $20^{\circ} \mathrm{C}$ despite of greatly increased ventilation efforts. Daylength was maintained at 20 hours and artificial lighting was kept continuously switched on, except for the very end of the experimental period when there was adequate sunlight and the additional rise in temperature caused by the lights had to be avoided. 
The plants were harvested at five different stages of development:

1. Lateral shoots formed

2. Culm growth initiated, first node visible

3. Awns emerged

4. Anthesis passed, grains filling

5. Full maturity

Harvest was performed when majority of the plants in a pot were considered to represent the appropriate stage of development.

After harvest the plants were analysed individually as follows: the culms were counted; dry weights were dețermined separately for leaves, culms, roots and ears; on plants harvested at full maturity the ears were measured for their length and subsequently threshed for determinations of 1000-grain weight and nitrogen content of the grain yield.

\section{Results}

Rate of development

At $20^{\circ} \mathrm{C}$ the seedlings emerged within an average of 6,5 days. At $10^{\circ} \mathrm{C}$ seedling emergence tokk nearly double that time, 12,8 days. In the early stages of vegetative growth, development was at the higher temperature almost twice as fast as at the lower temperature, but the difference became much smaller by the time of awn emergence. At this point the number of accumulated growth days was 47,5 at $20^{\circ} \mathrm{C}$ and 81,4 at $10^{\circ} \mathrm{C}$. After the ears appeared it became impossible to maintain the lower growth temperature at $10^{\circ} \mathrm{C}$ with the result that the relative difference between the growth rates grew smaller in the course of plant maturation. At final harvest the number of growth days was 92,7 for the plants grown at $20^{\circ} \mathrm{C}$ and 135,0 for those grown at $10^{\circ} \mathrm{C}$. There was no appreciable difference in growth rate between plants in sparse and dense populations at $10^{\circ} \mathrm{C}$, whereas at $20^{\circ} \mathrm{C}$ the dense populations reached the stage of awn emergence 1,5 days earlier than the sparse populations and the difference widened further towards full maturity which in the dense stands occurred an average of 11 days earlier than in the thin stands. The varietal differences in rate of development agreed with those anticipated.

Total dry-matter yield

In early stages of growth the total dry-matter yield or biological yield per pot was for all varieties significantly larger in dense than in sparse populations. At the last harvest the dry-matter yields of Arvo and Birgitta barleys grown at the lower temperature were higher in the sparse than in the dense populations. The rest of the two-rowed varieties, all multi-rowed varieties, and Arvo and Tammi at the higher temperature maintained higher total amounts of dry matter in the dense populations. Dry matter per individual 


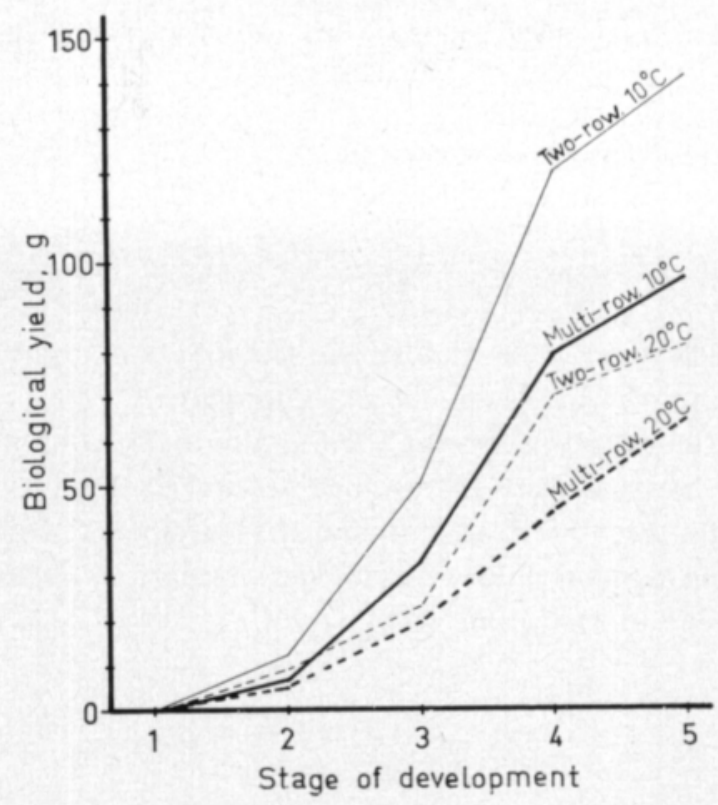

Fig. 1. Total biological yield per pot of the two- and multi-rowed barley varieties in sparse populations at temperatures $10^{\circ}$ and $20^{\circ} \mathrm{C}$.

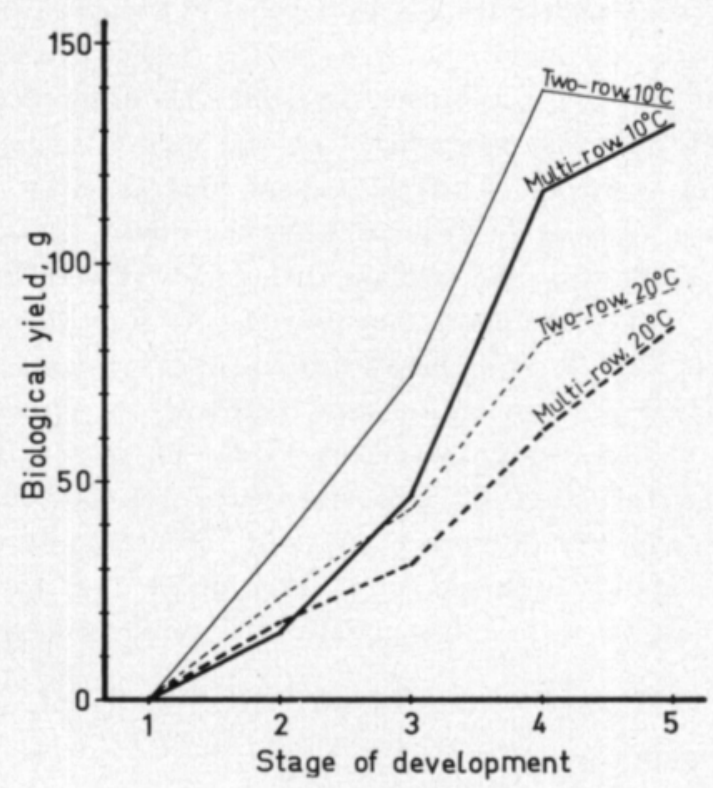

Fig. 2. Total biological yield per pot of the two- and multi-rowed barley varieties in dense populations at temperatures $10^{\circ}$ and $20^{\circ} \mathrm{C}$.

plant was consistently larger in sparse populations for each of the varieties at every harvest. Low temperature increased the total yield significantly at both densities. The two-rowed varieties gave larger total yields per pot (Figs. 1 and 2) and per individual plant than the multi-rowed varieties at both 


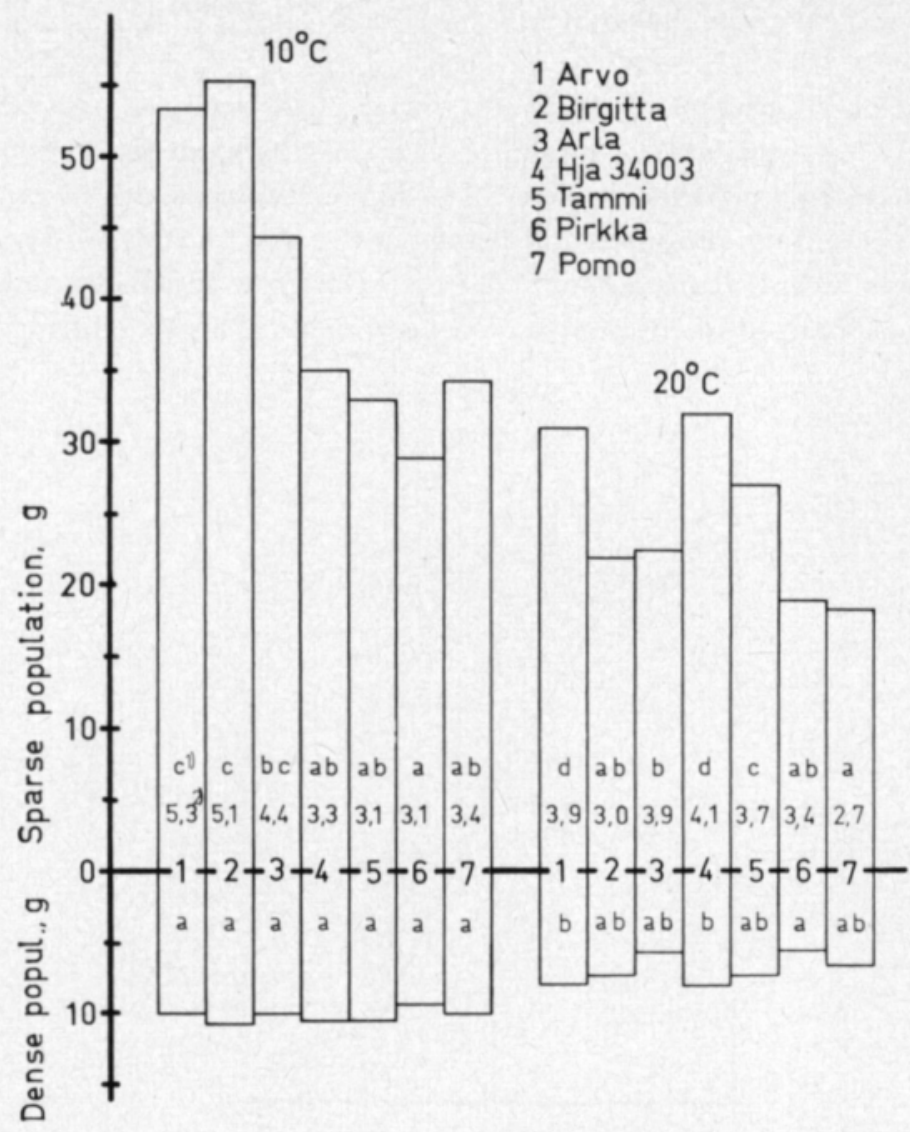

Fig. 3. Total biological yield of the barley varieties at full maturity in sparse and dense populations at $10^{\circ}$ and $20^{\circ} \mathrm{C}$.

1) Columns within any temperature and density group which are marked by the same letter indicate results which in the Duncan test do not differ from each other significantly when $\mathrm{P}=5 \%$.

$\left.{ }^{2}\right)$ Sparse stand/dense stand ratio.

densities and both temperatures, the difference being largest in sparse stands at the lower temperature. Marked differences occurred in dry matter of the different varieties. Fig. 3 presents the varietal dry weights at the last harvest. There were no differences between the dense populations at $10^{\circ} \mathrm{C}$. Pirkka was the poorest yielding variety at $20^{\circ} \mathrm{C}$ but differed significantly only from Arvo and $\mathrm{Hja} 34003$, the two most successful varieties in terms of total yield in these less favourable conditions. In sparse populations two-rowed $\mathrm{Hja}$ 34003 and all the multi-rowed varieties yielded significantly less at $10^{\circ} \mathrm{C}$ than the other two-row varieties. At $20^{\circ} \mathrm{C}$, however, $\mathrm{Hja} 34003$ produced the highest yield of all. The reduction in its yield as compared with the $10^{\circ} \mathrm{C}$ regime was a mere $9 \%$, while the corresponding yield reductions for the other varieties were Arvo $42 \%$, Birgitta $60 \%$, Arla $49 \%$, Tammi $18 \%$, Pirkka $33 \%$, and Pomo $47 \%$. The sparse/dense stand yield ratios for the different varieties are shown in Fig. 3. 
The portion of leaves fell from an initial $50 \%$ towards the stage of full maturity. It was ultimately no more than $8-26 \%$ depending on variety, temperature and population density. The higher temperature increased significantly the percentage proportion of leaves in the dry-matter yield as compared with the lower temperature regime. The effect of growth density on the percentage of leaves changed in the course of development (Fig, 4). During vegetative

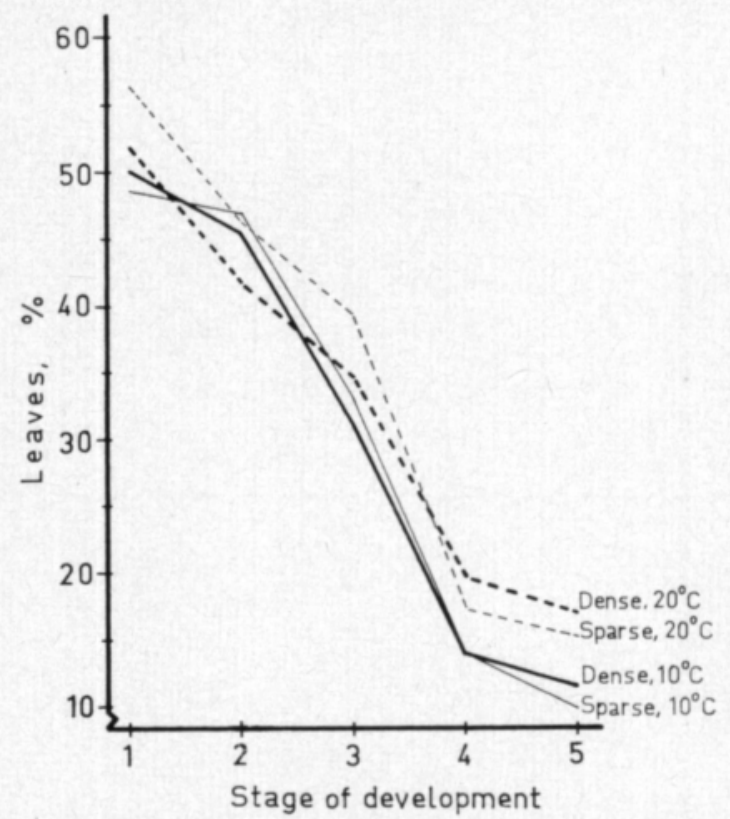

Fig. 4. Leaves per cent of total biological yield in sparse and dense populations at $10^{\circ}$ and $20^{\circ} \mathrm{C}$.

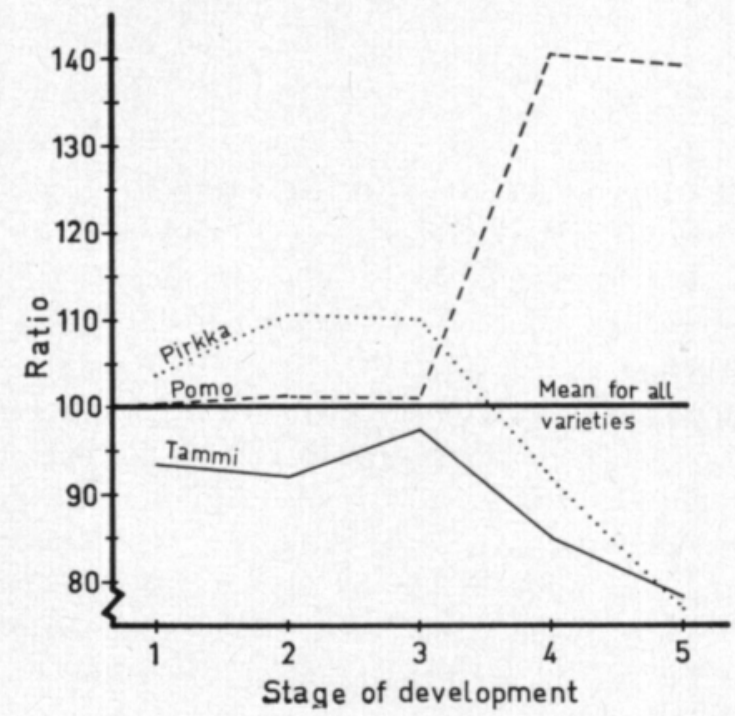

Fig. 5. Leaves per cent of total biological yield in the multi-rowed varieties as compared with the mean for all varieties. 
growth the sparse populations had larger numbers of leaves than the dense populations. When ears began to emerge, the proportion of leaves fell noticeably more in sparse than in dense stands until at full maturity it was nearly significantly less in the former. The two groups of varieties did not differ from each other in terms of leafiness but there were significant differences between single varieties. Tammi very clearly had the scarcest leaves. Pomo and Birgitta were especially leafy. Pirkka had a higher than average proportion of leaves in early growth but lower than average in the late stages of growth. In contrast, Pomo had fewer leaves at the outset of growth but increased their number strongly later. Fig. 5 shows the proportions of leaves in Tammi, Pirkka and Pomo as compared with the averages for all varieties tested.

Percentage of culms in dry matter

At the first harvest the proportion of culms was $22-31 \%$ of dry matter. As growth proceeded the percentage of culms increased, the average figure being $54 \%$ at the third harvest when ears had already been initiated within the flag-leaf sheaths to add considerably to the weight of culms. Still at the fourth harvest, with some of the ears still enclosed in the leaf sheaths, the proportion of culms was higher than in fully matured plants even though most ears had already emerged and were considered separately from the culms. In fully matured plants the proportion of culms varied from 24 to $44 \%$ depending on variety, temperature and growth density. At every harvest but the first, the proportion of culms was higher in plants grown at the lower temperature (Fig. 6). The effect of density on proportion of culms varied

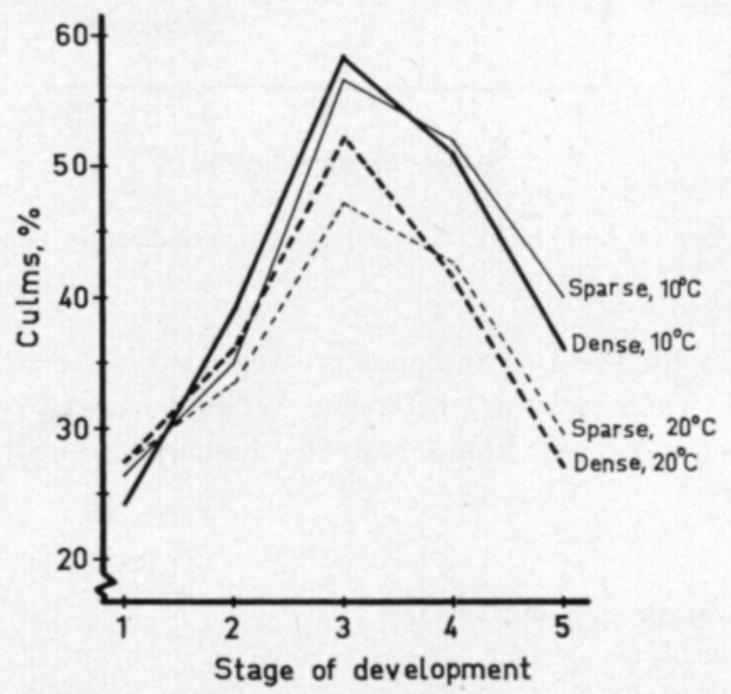

Fig. 6. Culms per cent of total biological yield in sparse and dense populations at $10^{\circ}$ and $20^{\circ} \mathrm{C}$. 
according to the stage of development. At the first harvest there were no noteworthy differences between plants grown at different densities; at the second and third harvests the dense populations had significantly larger proportions of culms; at the fourth harvest both densities produced approximately equal results; and at the fifth harvest the sparse populations had significantly larger proportions of culms than the dense ones. The two types of barley did not differ in this respect. Some significant differences occurred between varieties. Pomo had a lower proportion of culms than the other varieties, and Arvo had a higher proportion of culms especially when grown at the higher temperature.

Percentage of roots in dry matter

The percentage proportion of roots in dry matter was at the first harvest $21-28 \%$ at the lower temperature and $13-24 \%$ at the higher temperature. At full maturity the respective figures were $3-5 \%$ and $3-7 \%$. Growth density did not affect significantly the percentage of roots (Fig. 7). The

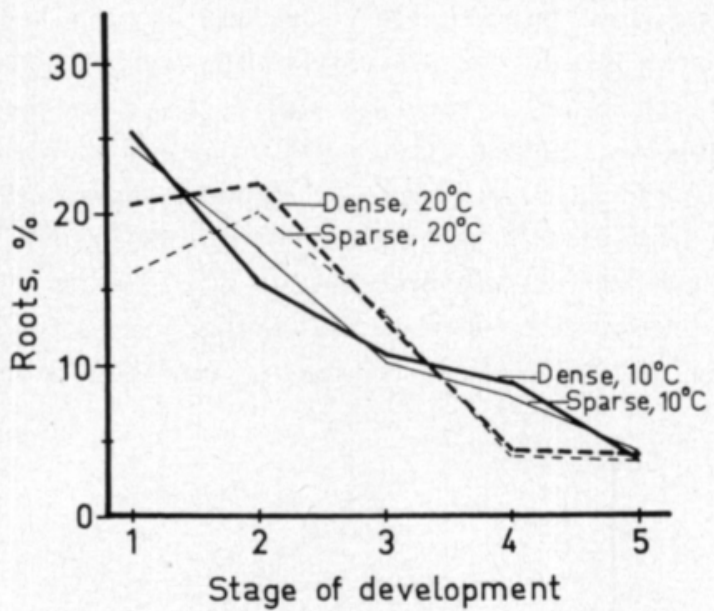

Fig. 7. Roots per cent of total biological yield in sparse and dense populations at $10^{\circ}$ and $20^{\circ} \mathrm{C}$.

differences caused by the two temperature regimes varied at different stages of development. There was no difference between the two types of barley. Of the individual varieties, Pomo had the highest proportion of roots and Arvo the lowest.

Percentage of ears in dry matter

At the fourth harvest, carried out when majority of the ears had begun to fill, some of the later ears still remained enclosed in the sheaths thus contributing to the weight of the culms. Ears constituted $23-42 \%$ of the dry 
matter at the fourth harvest and $42-57 \%$ at the fifth, depending on variety and growth temperature. The last-mentioned factor had a very significant effect on the proportion of ears. The higher temperature increased the figure from 26 to $35 \%$ in the fourth and from 47 to $51 \%$ in the fifth harvest with all varieties and both densities taken into consideration. Density, on the other hand, had no appreciable effect on the proportion of ears. Significant differences were found between the varieties (Fig. 8); ear development in

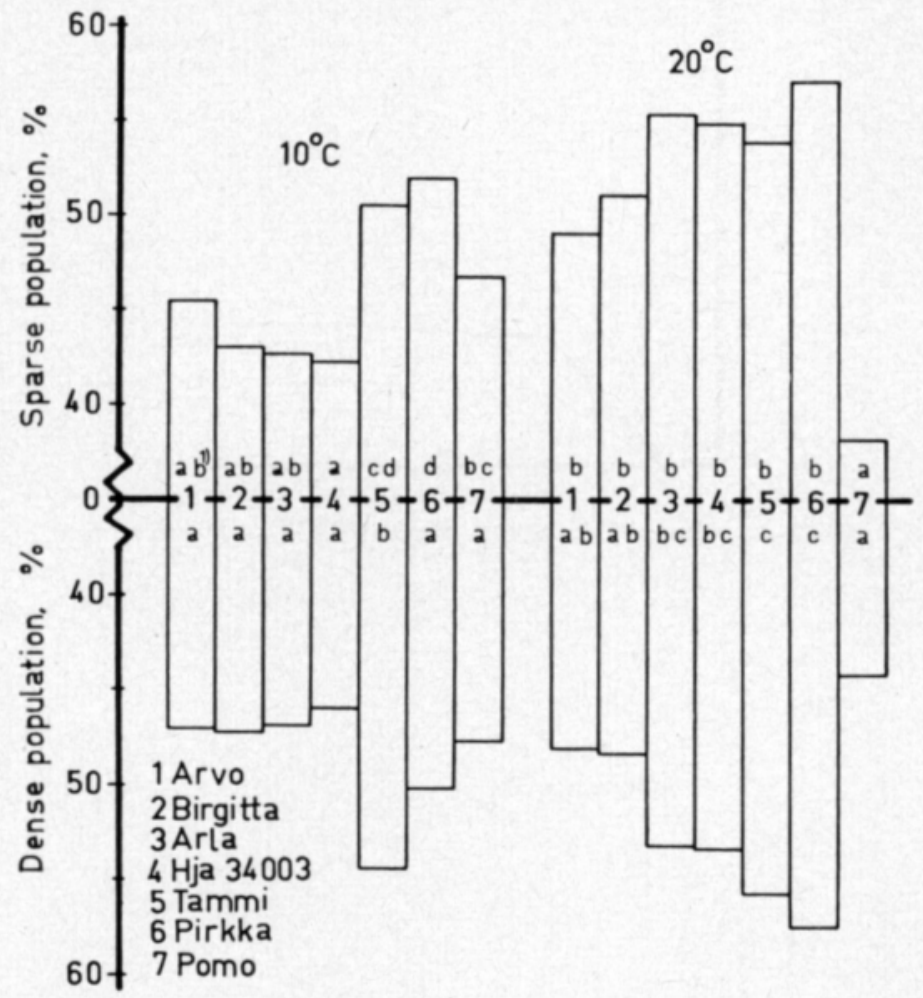

Fig. 8. Ears per cent of total biological yield of the barley varieties at full maturity in sparse and dense populations at $10^{\circ}$ and $20^{\circ} \mathrm{C}$.

1) Duncan test. See explanation in Fig. 3.

Pomo, for instance, was badly hampered by high temperature. At the lower temperature the multi-rowed varieties had significantly larger proportions of ears than had the two-rowed varieties.

Number of culms

Considering the whole plant material, growth temperature did not affect the number of culms per pot or individual plant. Of the different varieties, Pomo at the second and third harvests had a significantly larger number of culms at $20^{\circ} \mathrm{C}$ than at $10^{\circ} \mathrm{C}$. In sparse population at $20^{\circ} \mathrm{C}$ Pomo had the second largest number of culms in the early stages of growth, but in the later stages at $20^{\circ} \mathrm{C}$, and consistently at the lower temperature, Pomo was next 
to the last variety, Pirkka, in terms of number of culms. In the dense treatment, due to its more than fourfold number of plants, the number of culms per pot was naturally significantly higher than in the sparse treatment. For the same reason the number of culms per individual plant was higher in sparse than in dense stands. There was no increase in culm numbers with progress of growth in the multi-rowed varieties (Fig. 9), the numbers remained fairly

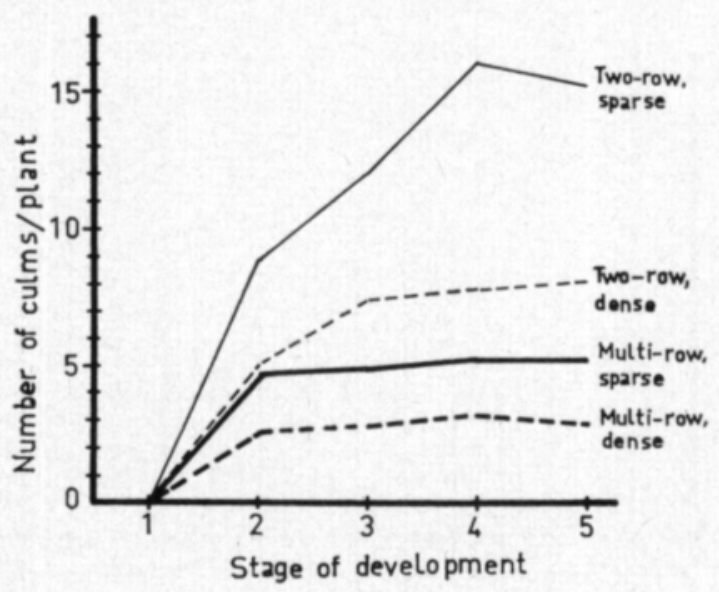

Fig. 9. Number of culms per plant of the two- and multi-rowed varieties in sparse and dense populations.

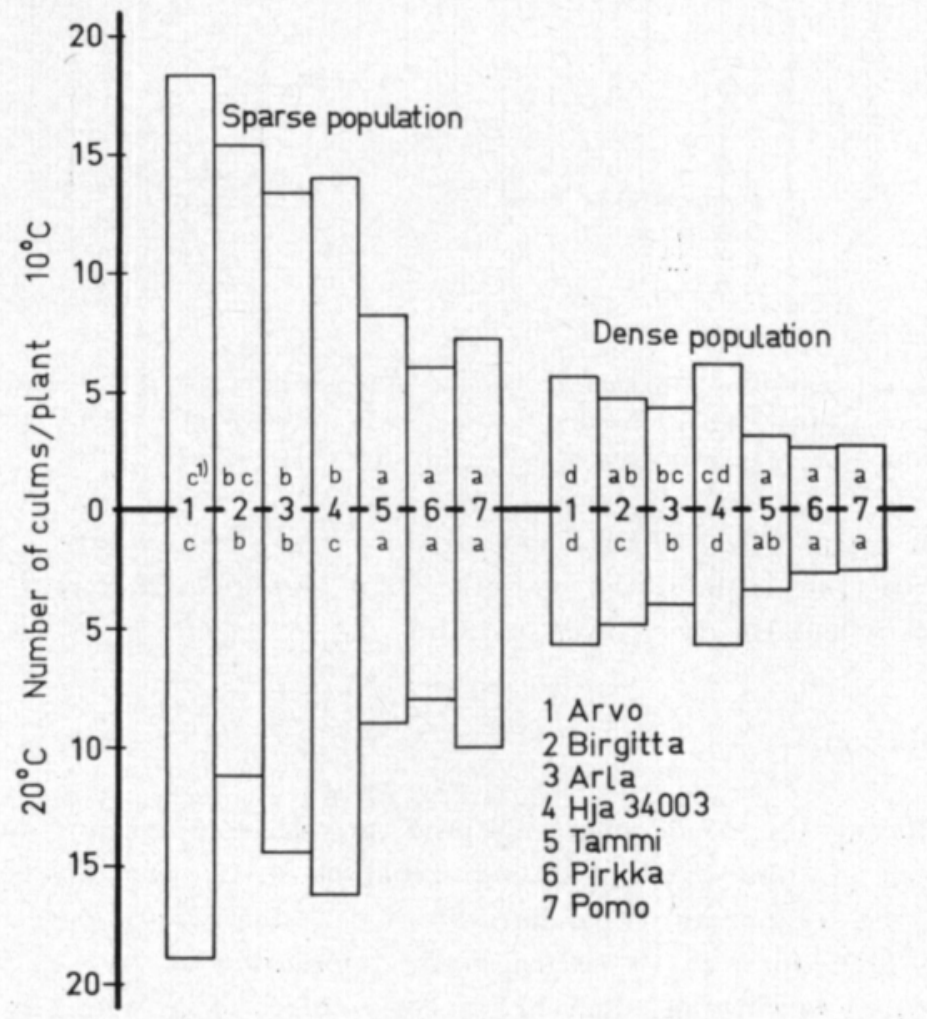

Fig: 10. Number of culms per plant of the barley varieties at full maturity in sparse and dense populations at $10^{\circ}$ and $20^{\circ} \mathrm{C}$.

2) Duncan test. See explanation in Fig. 3. 
constant from the second harvest to the fifth. In contrast, the two-rowed varieties, especially in sparsely sown treatments showed significant increases in culm numbers all the way from the first to the fourth harvest.

As expected, the two-rowed varieties carried significantly more culms than the multi-rowed varieties at all harvests (Fig. 9). Since the numbers of culms per pot corresponded fully to the numbers of culms per plant, the latter results only are given in Fig. 10, for all varieties at full maturity.

Number and length of ears

The number of ears followed that of the culms, being only 0,5 less on the average. An exception was Pomo in sparse population at $20^{\circ} \mathrm{C}$ with 10,0 culms but only 5,7 ears per individual plant. The varieties displayed large differences in ear length (Fig. 11). Low temperature increased the ear length slightly. In thin populations the ears were significantly longer than in dense populations.

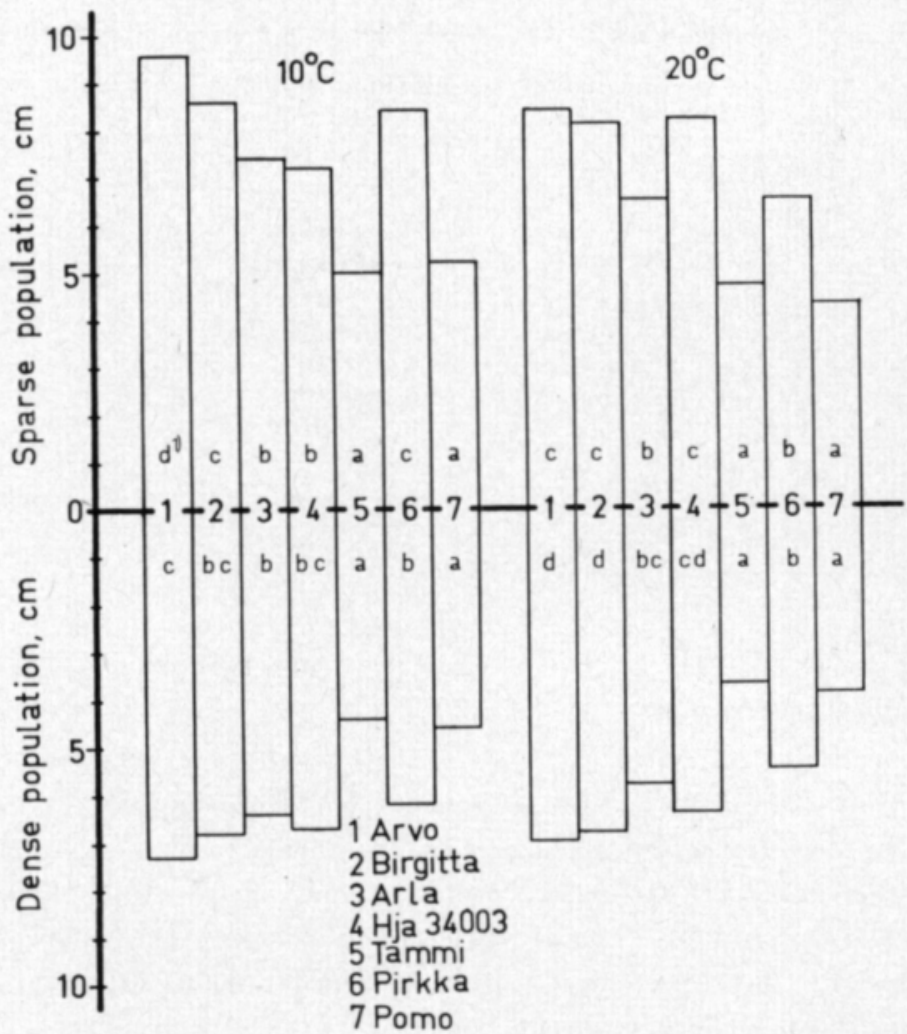

Fig. 11. Ear length of the barley varieties in sparse and dense populations at $10^{\circ}$ and $20^{\circ} \mathrm{C}$. 1) Duncan test. See explanation in Fig. 3. 
Number of grains per ear

Growth density did not affect the number of grains per ear. Low temperature, on the other hand, had an increasing effect on the grain number (Fig. 12). The largest differences due to temperature appeared in the multi-rowed varieties.

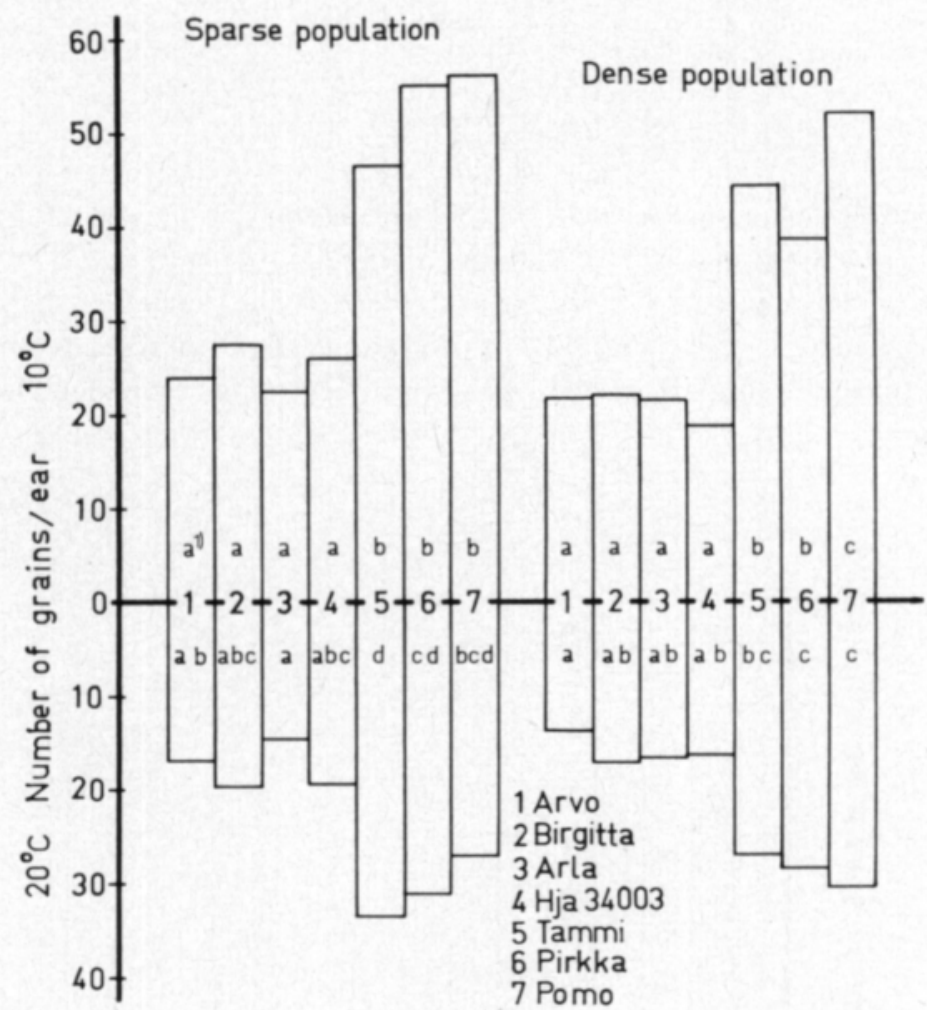

Fig. 12. Number of grains per ear of the barley varieties in sparse and dense populations at $10^{\circ}$ and $20^{\circ} \mathrm{C}$.

1) Duncan test. See explanation in Fig. 3.

1000 -grain weight

The grains produced in sparse populations were significantly larger than those produced in dense populations. The variation in grain weight at different spacings was, however, strongly dependent on variety (Fig. 13). Considering all the varieties studied, temperature did not affect the 1000 -grain weight. Fig. 13 reveals, however, that different combinations of temperature and spacing produced different effects on the varieties. In sparse populations, for instance, $\mathrm{Hja} 34003$ and Tammi benefited from high temperature. In dense populations Arvo and Pomo produced larger grains at $20^{\circ} \mathrm{C}$ than at $10^{\circ} \mathrm{C}$. 


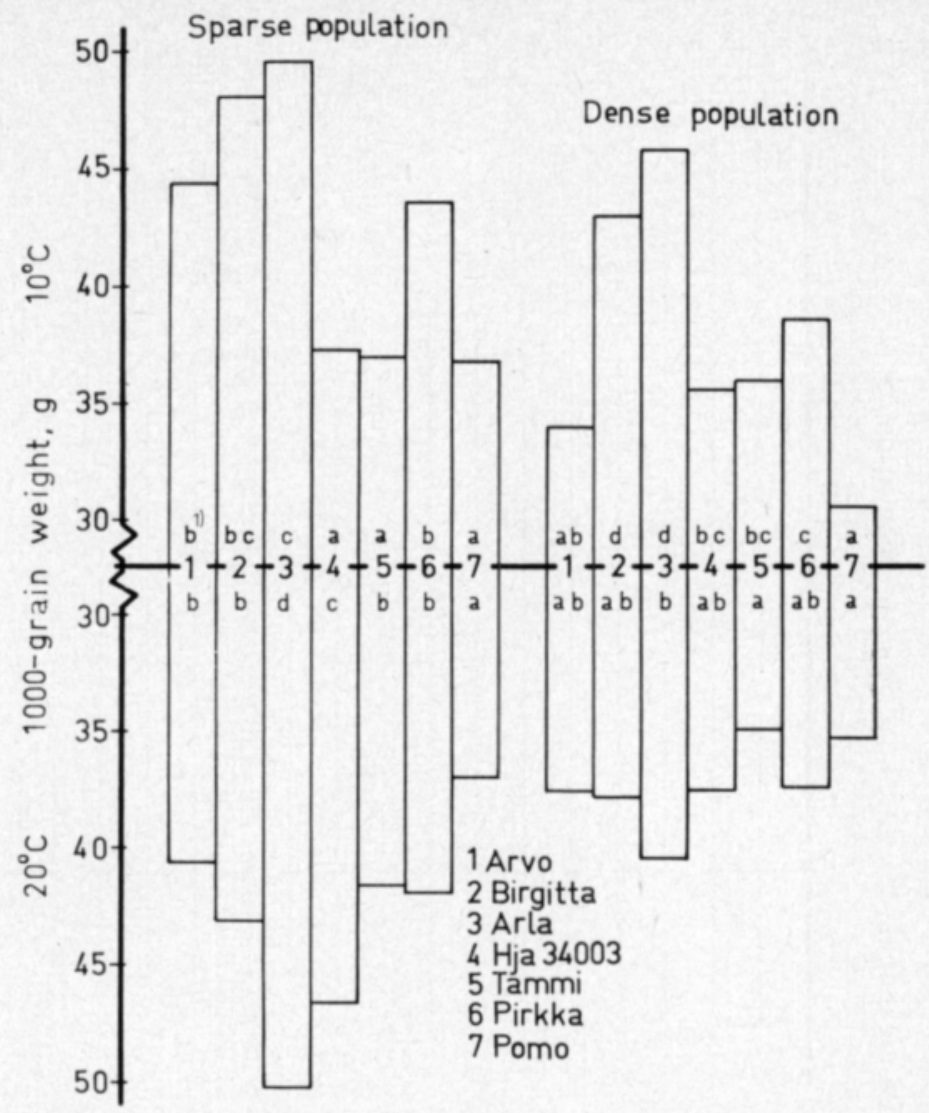

Fig. 13. 1000-grain weight of the barley varieties in sparse and dense populations at $10^{\circ}$ and $20^{\circ} \mathrm{C}$.

1) Duncan test. See explanation in Fig. 3.

\section{Grain yield}

At the lower temperature the average grain yield for all varieties was 47 $\mathrm{g} /$ pot from sparse populations and $56 \mathrm{~g} /$ pot from dense populations. At the higher temperature the respective figures were 32 and $39 \mathrm{~g} /$ pot. Thus the dense stands yielded slightly better, although divergent and even opposite results were obtained for some varieties which also were statistically significant. With one exception the grain yield was higher from plants grown at the lower temperature; the exception was $\mathrm{Hja} 34003$ which in sparse stands produced $38 \mathrm{~g} /$ pot at $10^{\circ} \mathrm{C}$ and $44 \mathrm{~g} /$ pot at $20^{\circ} \mathrm{C}$. It seemed apparent that in the dense stands, too, $\mathrm{Hja} 34003$ tolerated the higher temperature better than did the other varieties. The varietal grain yields per plant under different combinations of spacing and temperature are presented in Fig. 14. At the lower temperature the average grain yield per plant was $16 \mathrm{~g}$ in the sparse and 4 in the dense stands. Respective figures for the higher temperature were 11 and $3 \mathrm{~g}$. The results show that ample growth space and low tempera- 


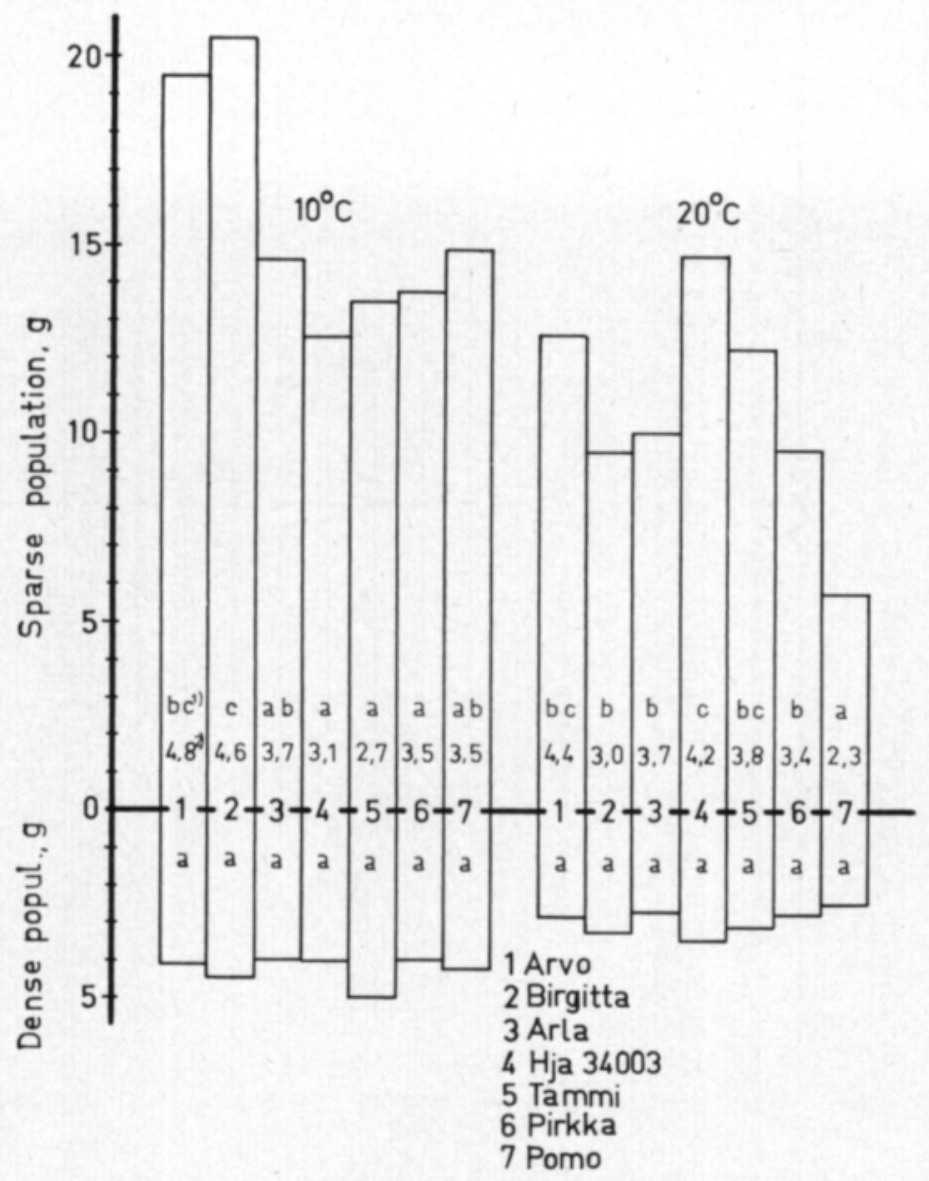

Fig. 14. Grain yield per plant of the barley varieties in sparse and dense populations at $10^{\circ}$ and $20^{\circ} \mathrm{C}$.

1) Duncan test. See explanation in Fig. 3.

$\left.{ }^{2}\right)$ Sparse stand/dense stand ratio.

ture promoted the grain yield. The sparse stand/dense stand yield ratios of the varieties (Fig. 14) correspond well to the respective ratios in total dry matter (Fig. 3). The two-rowed barleys gave a slightly higher average grain yield than the multi-rowed barleys.

\section{Nitrogen content}

Grain nitrogen content was significantly higher in the sparse than in the dense stands. Of the pots with dense spacing all those kept at $20^{\circ} \mathrm{C}$ produced grain with higher nitrogen content than those at $10^{\circ} \mathrm{C}$. The sparse populations showed no significant response to temperature, and some of the varieties even 
produced lower nitrogen contents at $20^{\circ} \mathrm{C}$ than at $10^{\circ} \mathrm{C}$ (Fig. 15). There was no difference between the two- and multi-rowed varieties, and some rather large differences that were found between single varieties were not statistically significant.

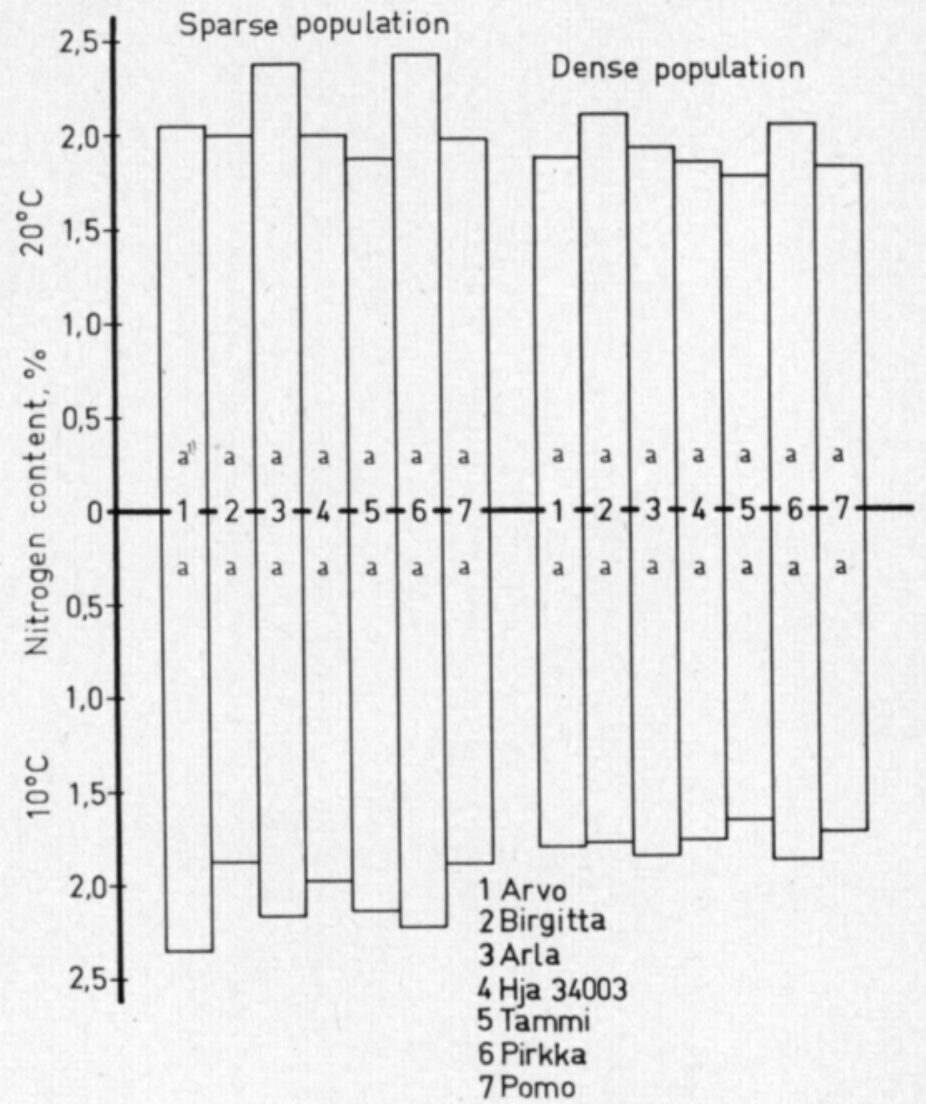

Fig. 15. Grain nitrogen content of the barley varieties in sparse and dense populations at $10^{\circ}$ and $20^{\circ} \mathrm{C}$.

1) Duncan test. See explanation in Fig. 3.

Correlations between grain yield and some factors affecting it

Grain yield was most affected by total biological yield, number of culms, 1000-grain weight and number of grains per ear, all of which were in a highly significant positive correlation with the grain yield (Table 1). The number of culms explained a larger proportion of the yield than the other yield components for both groups of varieties. The correlation coefficients were $+0,887$ for the two-rowed and $+0,604$ for the multi-rowed barleys, the difference being due to the higher number of culms in the two-rowed varieties. The weight of 1000 grains explained a slightly larger proportion, and the grain 


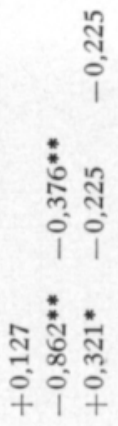

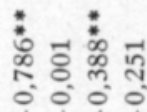

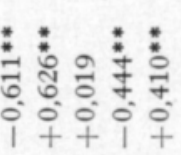

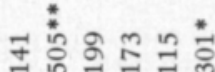
$1+1+$
$+1+1+0$

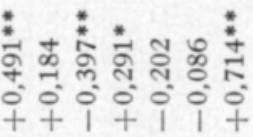
* +otio itio * $+0000000$

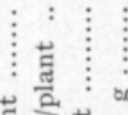

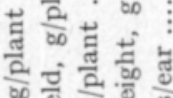

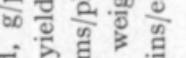

त)

万ู ฮี छี

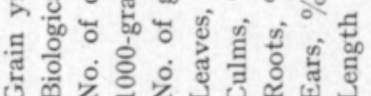

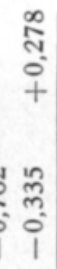

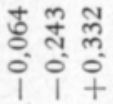

* * * : * :

iิ

$i+i$ i

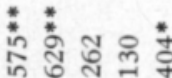

$1+000$

ลิ

i itio

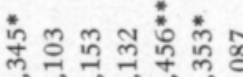

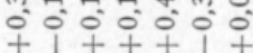

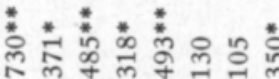
o 0.0 十+十17+1

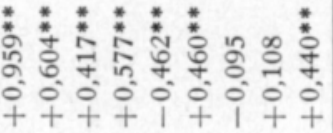

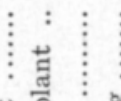

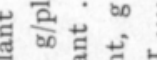

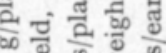

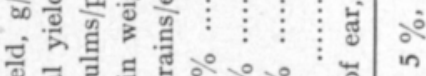

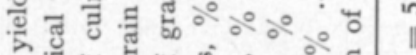

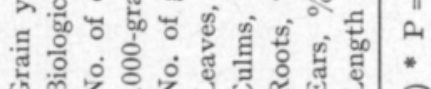


number per ear a slightly lesser proportion, of the yield of the two-rowed varieties than of that of the multi-rowed varieties. The positive correlation between ear length and grain yield was stronger for the two- than for the multi-rowed varieties due to differences in their ear structure. The significant negative correlation between leaf percentage and grain yield $(-0,568$ for the two-rowed and $-0,462$ for the multi-rowed) is understandable since the percentages of leaves and culms are inversely proportional and also because the number of culms explains most of the yield obtained.

Since there was a very strong positive correlation between grain yield and total biological yield the relations of the other attributes to the biological yield were similar to those to the grain yield.

In both groups of varieties there was a significant positive correlation between number of culms and 1000-grain weight. Neither of these characters, on the other hand, had any noteworthy correlation with the number of grains per ear.

The two types of barley differed in some other characteristics studied. Thus the correlation between number of culms and leaf percentage was a significant negative one for the two-row barleys, while that for the multirow varieties was slightly positive. A difference in the same direction was found in the correlations between number of culms and percentage of roots. The two types also differed from each other in leaves/roots ratio and in the correlations between percentage proportions of leaves and ears.

\section{Discussion}

The barley varieties in this study produced significantly larger dry-matter yields at a low temperature $\left(10^{\circ} \mathrm{C}\right)$ than at a higher one $\left(20^{\circ} \mathrm{C}\right)$. The response of individual varieties to temperature varied considerably. The favourable effect of low temperature was also established by FARIs et al. (1969) with day-neutral Olli and long-day Vantage barleys. At a high temperature level wheat has been found to respond to a rise in growth temperature from $20^{\circ}$ to $25^{\circ} \mathrm{C}$ by increasing its total dry matter, leaf area and number of culms (FRIEND 1965 and 1966, FRIEND et al. 1962 and 1965). At a lower temperature level CAMPBELL et al. (1968) arrived at diverging results with a different variety. They found that a rise in temperature from $13^{\circ}$ to $21^{\circ} \mathrm{C}$ produced a decline in yield which was attributed to a decrease in leaf size as well as to thinner and shorter culms. For barley, however, the optimum temperature obviously is much lower than the $20^{\circ} \mathrm{C}$ claimed by FRIEND (1966) to be the optimum for wheat.

The percentage proportion of leaves was larger at the higher temperature, as was also found with wheat (FRIEND 1966). In contrast, the percentage of culms was at the lower temperature higher than at the higher temperature; LANGER (1963) considers this a common phenomenon in all graminaceous plants. According to FRIEND et al. (1965) percentage of roots is highest at low temperature and high illumination. In our experiments it was found that at the first harvest and after heading roots were more abundant in plants 
growing at the low temperature, but from beginning of tillering to the end of vegetative growth their percentage was at the high temperature higher than at the low temperature. It is arguable, on the other hand, whether the underground parts of plants growing in optimal conditions of nutrition and moisture but in restricted space are fully comparable with those of plants growing in totally natural conditions.

It is difficult to estimate the significance to grain yield of the variation that occurs in the proportions of various plant organs in the course of growth. A closer inspection of the results obtained with the varieties Arvo and Birgitta, which gave grain yields larger than any other variety in the sparse stands at $10^{\circ} \mathrm{C}$, and the variety $\mathrm{Hja} 34003$, highest yielding at $20^{\circ} \mathrm{C}$ at the same density, shows that there was nothing exceptional about the distribution of biological mass in the different phases of development that would have explained the size of the grain yield. Instead, the total biological yield of Arvo and Birgitta at $10^{\circ} \mathrm{C}$ increased in the course of development faster than the yield of the other varieties, and was at the end of experiment very significantly higher than that of the others. The total biological yield of the variety $\mathrm{Hja} 34003$, which gave a high grain yield at $20^{\circ} \mathrm{C}$, was likewise large from the very beginning and exceeded that of the other varieties over the entire growing period. In the corresponding low-temperature treatment, where the grain yield of $\mathrm{Hja} 34003$ was low, the biological yield of the variety was likewise high in the early stages of development. Its accumulation, however, slowed down when ears began to emerge and the result was low yielding at the later harvests as compared with the other two-row varieties.

Ear length in Arvo and Birgitta in sparse populations was significantly larger at the low temperature than at the high temperature. In $\mathrm{Hja} 34003$ the average ear grown at $20^{\circ} \mathrm{C}$ was $1 \mathrm{~cm}$ longer than that grown at $10^{\circ} \mathrm{C}$. In Arvo and Birgitta the longer ear produced more grains per ear than the shorter ear grown at the higher temperature, although ear length may have contributed little to the low grain number at $20^{\circ} \mathrm{C}$. In $\mathrm{Hja} 34003$ the increased ear length did not affect significantly the number of grains per ear, but 1000 -grain weight was very significantly higher in the longer ears than in the shorter ears grown at $10^{\circ} \mathrm{C}$. Similarly the 1000 -grain weight for the longer ears of Arvo and Birgitta was higher than that for their shorter ears.

Leaf surface area, and especially that of the flag leaf (WATson et al. 1963), is an important factor determining the grain yield. Not only leaves but also leaf sheaths, culms and peduncles as well as the ears themselves are active in photosynthesis (THORNE 1966), and it is therefore difficult to demonstrate that varietal differences in grain yield were due to differences e.g. in leaf size (LANGER 1967). According to ThORNE (1966) most of the carbohydrate in barley grain originates from post-heading assimilation of carbon dioxide, and growth before heading has but an indirect effect on the size of the grain yield. In the present study the variety Birgitta, which was found especially leafy, exceeded the other varieties in grain yield at the lower temperature. Another leafy variety, Pomo, on the other hand, did not surpass the less leafy varieties in grain yield. Indeed at the higher growth temperature the grain yield of Pomo was poorest of all. Since the number of culms is the principal factor 
determining the grain yield, the poor yield of Pomo was not totally unexpected, for although this variety initially produced a large number of culms even at the higher temperature, it subsequently fell behind and by the time of final harvest almost equalled the poorest variety, Pirkka, in terms of number of culms. Pomo obviously suffered from high temperature more than the other varieties studied.

The size of grain yield depended mainly on the total biological mass. Of the actual yield components - number of headed culms, number of grains per ear, and grain size - the number of culms was the most important factor (Table 1). The correlation between grain yield and number of headed culms was stronger for the two-rowed varieties $(r=0,887)$ than for the multi-rowed varieties $(r=0,604)$ with scarcer tillering. In the two-row barleys number of grains per ear and 1000-grain weight explained nearly equal proportions of the grain yield $(r=0,521$ and $r=0,596)$ while in the multi-rowed varieties the respective correlation coefficients were $r=0,577$ and $r=0,417$. These results disagree with those of FARIs et al. (1969) who found that the number of grains per ear explained most of the yield while the effects of grain size and number of ears were less and between them of approximately equal importance. It is understandable that the significance of the various yield components as yield factors should vary with varying mutual competition situations brought about by varying circumstances, e.g. changes in growth density.

\section{REFERENCES}

AspinaL, D. 1966. Effects of day length and light intensity on growth of barley. IV. Genetically controlled variation in response to photoperiod. Aust. J. Biol. Sci. 19:517-534. 1969. VI. Interactions between the effects of temperature, photoperiod, and the spectral composition of the light source. Aust. J. Biol. Sci. 22: 53-67.

- - \& PAleg, L. G. 1964. III Vegetative development. Aust. J. Biol. Sci. 17: 807-822.

CAMpbell, C. A. \& READ, D. W. L. 1968. Influence of air temperature, light intensity and soil moisture on the growth, yield and some growth analysis characteristics of Chinook wheat grown in the growth chamber. Can. J. Plant Sci. 48: 299-311.

FARIS, D. G. \& GuITARD, A. A. 1969. Yield and primary culm yield components of two spring barley cultivars as influenced by temperature, daylength and growth stage. Can. J. Plant Sci. 49: 701-713.

Friend, D. J. C. 1965. Ear length and spikelet number of wheat grown at different temperatures and light intensities. Can. J. Bot. 43: 345-353.

,- 1966 . The effect of light and temperature on the growth of cereals. The growth of cereals and grasses: 181-199. Ed. Milthorpe, F.L. and Ivins, J. D. London.

- - Fisher, J. E. \& Helson, V. A. 1963. The effect of light intensity and temperature on floral initiation and inflorescence development of Marquis wheat. Can. J. Bot. 41: $1663-1674$.

- - Helson, V. A. \& Fisher, J. E. 1962. The rate of dry weight accumulation in Marquis wheat as affected by temperature and light intensity. Can. J. Bot. 40: 939-955.

- - Helson, V. A. \& Fisher, J. E. 1965. Changes in the leaf area ratio during growth of Marquis wheat as affected by temperature and light intensity. Can. J. Bot. 43: $15-28$. 
Guitard, A. A. 1960. The influence of variety, temperature, and stage of growth on the response of spring barley to photoperiod. Can. J. Plant Sci. 40: 65-80.

LANGer, R. H. M. 1963. Tillering in herbage grasses. Herbage Abstracts 33: 141-148.

- - 1967. Physiological approaches to yield determination in wheat and barley. Field Crop Abstracts 20: 101-106.

Thorne, G. N. 1966. Physiological aspects of grain yield in cereals. The growth of cereals and grasses: 88-118. Ed. Milthorpe, F. L. and Ivins, J. D. London.

- Ford, M. A. \& Watson, D. J. 1968. Growth, development and yield of spring wheat in artificial climates. Ann. Bot. 32: 425-446.

Watson, D. J., Thorne, G. N. \& French, S. A. W. 1963. Analysis of growth and yield of winter and spring wheats. Ann. Bot. 27: 1-22.

\title{
SELOSTUS
}

\section{Lämpötilan ja tiheyden vaikutus kaksi- ja monitahoisten ohralajikkeiden kasvuun ja sadonmuodostukseen.}

\author{
KIRSTI ÄyräväInen ja Juhani PaAtela \\ Kasvinviljelytieteen laitos, Helsingin yliopisto, 00710 Helsinki
}

Helsingin yliopiston kasvinviljelytieteen laitoksella Viikissä suoritettiin kevättalvella 1971 kasvihuonekoe, jolla haluttiin selvittää lämpötilan ja tiheyden vaikutusta suomalaisten ohralajikkeiden kasvuun, biosadon jakautumiseen kasvissa sen eri kehitysvaiheissa ja sadonmuodostukseen. Erityisesti haluttiin selvittää eroja kaksi- ja monitahoisten ohratyyppien välillä.

Kokeessa oli mukana neljä kaksitahoista ohralajiketta, Arvo, Birgitta, Arla ja Hja 34003 sekä kolme monitahoista lajiketta, Tammi, Pirkka ja Pomo. Ohria kasvatettiin 10 ja $20^{\circ} \mathrm{C}$ :een lämpötiloissa käyttäen kahta tiheyttä, 3 ja 13 yksilöä astiaa kohti.

$20^{\circ} \mathrm{C}$ :ssa tapahtui vegetatiivinen kehitys lähes puolta nopeammin kuin $10^{\circ} \mathrm{C}: \mathrm{ssa}$. Reproduktiivisen vaiheen alettua pienentyi ero kehitysnopeudessa korkean ja matalan lämpötilan välillä. Matalassa lämpōtilassa saatiin kasveista huomattavasti suuremmat kokonaisbiosadot (Kuvat 1-3) sekä jyväsadot (Kuva 14) kuin korkeassa lämpötilassa. Lehtien (Kuva 4) ja tähkien (Kuva 8) prosenttinen osuus nousi korkeassa lämpötilassa. Korsien (Kuva 6) prosenttinen osuus sitä vastoin oli suurempi matalassa kuin korkeassa lämpötilassa. Korsilukuun (Kuva 10) ja 1000 jyvän painoon (Kuva 13) ei lämpötilalla yleensä ollut merkitsevää vaikutusta. Sen sijaan tähkän jyväluku (Kuva 12) oli suurempi matalassa kuin korkeassa lämpötilassa.

Tiheys ei matalassa lämpötilassa vaikuttanut kehitysnopeuteen, korkeassa lämpōtilassa kehittyivät tiheät kasvustot harvoja nopeammin. Kokonaisbiosato ja jyväsato olivat astiaa kohti tiheässä kasvustossa harvaa kasvustoa suuremmat. Yksilöä kohti taas harva kasvusto tuotti tiheää kasvustoa merkitsevästi suuremmat sadot (Kuvat 3 ja 14). Tiheyden vaikutus lehtien (Kuva 4) ja korsien (Kuva 6) prosenttiseen osuuteen vaihteli kasvun edistyessä; juurien ja tähkien prosenttiseen osuuteen tiheydellä ei ollut vaikutusta. Harvassa kasvustossa oli korsiluku yksilöä kohti suurempi (Kuvat 9 ja 10) ja astiaa kohti pienempi kuin tiheässä kasvustossa. Tähkän jyvälukuun (Kuva 12) ei tiheydellä ollut vaikutusta. Sen sijaan niin tähkån pituus (Kuva 11) kuin 1000 jyvän painokin (Kuva 13) kasvoivat harvassa kasvustossa tiheään verrattuna.

Kaksitahoisista lajikkeista saatiin merkitsevästi suurempi kokonaisbiosato (Kuvat 1-2) ja niukasti suurempi jyväsato (Kuva 14) kuin monitahoisista lajikkeista. Lehtien, korsien ja juurien prosenttisissa osuuksissa koko biosadosta ei ohratyyppien kesken ollut eroja. Korsiluku oli kaksitahoisissa lajikkeissa odotetusti monitahoisia merkitsevästi suurempi (Kuva 9), vastaavasti monitahoisissa lajikkeissa oli tähkän jyväluku suurempi kuin kaksitahoisissa lajikkeissa (Kuva 12). Kaksitahoisissa lajikkeissa oli yleensä monitahoisia korkeampi 1000 jy- 
vän paino (Kuva 13). Jyvien typpipitoisuudessa ei ohratyyppien kesken ollut eroja (Kuva 15).

Hja 34003 näytti sietäneen muita lajikkeita paremmin korkeaa lämpötilaa, jossa se ylti parhaaseen satoon. Korkeasta lämpötilasta kärsi pahoin erityisesti Pomo. Myős satoisimpien kaksitahoisten lajikkeiden sadon vähennys alhaiseen lämpötilaan verrattuna oli suuri harvassa kasvustossa. Lajikkeiden väliset satoerot tiheässä kasvustossa olivat pienet. Lajikkeiden välillä oli merkitseviä eroja satokomponenteissa ja biomassan jakautumisessa kasvin eri osiin.

Jyväsadon suuruuteen vaikuttivat eniten koko biosato, korsiluku, tähkän jyväluku ja 1000 jyvän paino (Taulukko 1). Satokomponenteista selitti korsiluku sadosta suurimman osan ( $\mathrm{r}=+0,887$ kaksitahoisilla ja $\mathrm{r}=+0.604$ monitahoisilla). Jyväluku tähkää kohti selitti kaksitahoisilla lajikkeilla sadosta niukasti vähemmän $(r=+0,521)$ ja 1000 jyvän paino niukasti enemmän $(r=+596)$ kuin monitahoisilla lajikkeilla $(r=+0,577$ ja $+0,417)$. Korsiluvun ja 1000 jyvän painon välillä oli merkitsevä positiivinen korrelaatio molemmissa ohratyypeissä. Sen sijaan tähkän jyväluvulla ei ollut korrelaatiota sen enempää korsiluvun kuin 1000 jyvän painonkaan kanssa. Korsiluvun ja lehtien ja juurien välisissä korrelaatioissa esiintyi eroja kaksi- ja monitahoisten ohratyyppien kesken.

Kasvin eri osien prosenttisella osuudella koko biosadosta kehityksen eri vaiheissa ei ollut vaikutusta jyväsadon muodostumiseen.

Pidentynyt tähkä vaikutti satoa lisäävästi joko tuottamalla enemmän jyviä tähkää kohti tai lisäämällä jyvån painoa. 